\title{
Para além da religião? Justiça de Deus, justiça do homem e as representações visuais do Juízo Final
}

\author{
Beyond religion? Justice of God, justice of man and visual representations of \\ the Last Judgment
}

\section{Tamara Quírico $^{1}$}

RESUMO

O presente artigo inicia com um breve comentário sobre as relações entre o Cristianismo e imagens (que encontram suas origens ainda nos primeiros séculos da era cristã), analisando em seguida de forma sucinta questões ligadas às funções que se esperavam que imagens religiosas cumprissem no Ocidente medieval. Após essas considerações, o artigo analisará possíveis interpretações sócio-políticas de representações visuais do tema do Juízo Final especialmente nos últimos séculos da Idade Média, focando em particular exemplos produzidos na Península Itálica. Para tanto, discutirá brevemente os desenvolvimentos de conceitos como justiça e julgamento, mostrando como, ao fim, análises sóciopolíticas dessas pinturas estariam necessariamente relacionadas também às funções religiosas dessas mesmas imagens.

Palavras-chave: Juízo Final. Justiça. Julgamento. Pintura Medieval. Funções das Images.

\section{ABSTRACT}

This article briefly considers the connection between Christianity and images, which began in the first centuries of Christian era. It then concisely analyzes topics related to the expected functions of religious images in Western medieval world. After these considerations, this article shall analyze possible sociopolitical interpretations of visual depictions of the Last Judgment, discussing particularly examples produced in the Italian Peninsula. It shall briefly discuss the development of concepts such as justice and judgment, and it shall demonstrate how such sociopolitical interpretations of these paintings would ultimately be related to the religious functions of these same images.

Keyword: Last Judgement. Justice. Judgement. Medieval painting. Functions of images.

${ }_{1}^{1}$ Professora Doutora da Universidade do Estado do Rio de Janeiro (UERJ). 


\section{Funções das imagens cristãs}

O Cristianismo é uma religião pródiga em imagens. A associação entre o culto religioso e as imagens vem desde os primeiros séculos quando, assimilando a iconofilia típica das tradições religiosas grecoromanas de que os primeiros conversos eram adeptos, os cristãos superaram o aniconismo e as interdições judaicas (de cujas tradições também eram herdeiros) quanto a seu uso em contextos religiosos ${ }^{2}$. A partir da aceitação das imagens, os seguidores da nova religião povoaram suas catacumbas e domus ecclesiae de representações visuais das histórias de Cristo e do Antigo Testamento, assim como de temas originalmente pagãos, reinterpretados, porém, em chave cristã ${ }^{3}$. Após a liberação do culto em 313, quando o Imperador Constantino publicou o Edito de Milão, o que hoje se denomina arte cristã passou a se desenvolver de forma exponencial, ocupando praticamente todos os espaços disponíveis nos edifícios religiosos que se multiplicaram por toda a Cristandade.

Não por acaso, Jérôme Baschet define as igrejas como um lieu d'images, um "lugar de imagens": de acordo com sua concepção, elas seriam "um objeto total, complexo, no qual as imagens se ligam entre si, se fundem com o lugar, e participam em sua função que é celebrar o culto de Deus e dos santos" (BASCHET, 1991, p. 6-7).

Baschet menciona em seu texto uma das funções possíveis para as imagens cristãs: inspirar o culto das figuras santas. Este, porém, não seria o único papel reservado a elas. No Ocidente medieval, o debate em torno das imagens religiosas se desenvolveu fundamentalmente a partir de duas cartas escritas por Gregório Magno (papa entre 590 e 604) ao bispo Sereno de Marselha, na virada do século VI para o VII. Nessa correspondência, o pontífice criticava supostas atividades iconoclastas promovidas pelo bispo em sua diocese, sem o seu conhecimento ou aprovação. Em uma das mais conhecidas passagens de seu texto, escreveu Gregório que "[...] o que a escrita é para os que sabem ler, a pintura é para os iletrados que a veem, pois nela os ignorantes veem aquilo que devem seguir; nela leem aqueles que desconhecem as letras. Assim,

\footnotetext{
${ }^{2}$ Há diversas passagens bíblicas que tratam dessa questão. Um dos trechos mais difundidos é, certamente, a seguinte passagem do Livro do Êxodo (20: 4-5) (BÍBLIA, 2004), talvez a mais conhecida com relação à proibição do uso de imagens no Antigo Testamento: "tu não farás nenhuma imagem esculpida, nada que pareça ao que está lá no alto nos céus ou aqui embaixo na terra, ou nas águas embaixo da terra. Tu não te prosternarás diante destas imagens nem as servirás, porque eu, lahweh, teu Deus, sou um Deus zeloso".

3 Para uma discussão mais aprofundada sobre questões relacionadas às imagens religiosas desde os primórdios do Cristianismo, ver Belting (2010) e Schmitt (2007), especialmente o capítulo "De Niceia II a Tomás de Aquino: a emancipação da imagem religiosa no Ocidente"; Baschet (2006), em particular o capítulo "A expansão ocidental das imagens". É importante destacar ainda como muitos medievalistas defendem hoje o termo imagem em detrimento de arte. De acordo com Jean-Claude Schmitt, por exemplo, até o século XV teriam predominado concepç̃̃es e práticas "não essencialmente estéticas, mas primeiramente cultuais e rituais das 'imagens'" (SCHMITT; LE GOFF, 2002, p. 592). Isso, por sua vez, justificaria a definição dada por Hans Belting de que a Idade Média seria o tempo das imagens e do culto: à era da imagem, portanto, Belting contraporia a era da arte. Segundo o autor, desenvolveu-se a partir do século XV uma discussão sobre o conceito mesmo de arte (que não existiria no Medievo), que teria, por sua vez, inserido "um novo nível de significado entre a aparência visual da imagem e a compreensão do observador" (BELTING, 2010, p. 17). Para uma análise sobre o conceito de imagem para o Ocidente medieval, ver o verbete "Imagens", em Schmitt e Le Goff (2002, p. 591-605).
} 
especialmente para os gentios, uma pintura toma o lugar da leitura"4. A máxima de Gregório Magno se tornou, com os séculos, uma das definições canônicas para as funções das imagens cristãs, e a referência mais importante no Ocidente na defesa de sua presença nas igrejas. Ela foi continuamente retomada ao longo dos séculos, com poucas variações, por teólogos tão proeminentes como São Boaventura (nascido Giovanni di Fidanza, ca. 1221-1274) e Santo Tomás de Aquino (1225-1274), dentre outros5.

Deve-se considerar, por outro lado, que a função didática das imagens, para a instrução dos leigos e iletrados (especialmente, mas não somente ${ }^{6}$ ) embora primordial, não era a única defendida pelo papa. De acordo com Gregório Magno, as imagens religiosas deveriam cumprir também outros papéis: elas deveriam despertar sentimentos de devoção nos fiéis (incentivando, portanto, o culto a Deus e aos santos de que tratara Baschet), bem como auxiliar a memorização de fatos ligados às histórias sagradas. Através desse conjunto de funções as imagens cristãs seriam um suporte essencial para a correta doutrinação e, por fim, poderiam levar, de forma eficaz, à conversão dos leigos.

\section{Funções das imagens cristãs para além da religião}

Uma questão importante não abordada seja por Gregório, nem por outros teólogos que seguiram seu pensamento sobre o papel das imagens religiosas, diz respeito a outras funções possíveis para as imagens cristãs. Com efeito, há que se considerar seu papel como um "ornamento social", por exemplo, para se seguir uma expressão utilizada por Bret Rothstein em seu estudo sobre a Flandres do século XV. Essas imagens, segundo o autor, poderiam ser um importante instrumento para se mostrar a respeitabilidade social daquele que encomendou a obra, bem como sua proeminência dentro daquele contexto social específico (ROTHSTEIN, 2005, p. 92-137).

É preciso ter em conta, do mesmo modo, a eventual importância das imagens cristãs como elemento de afirmação do poder secular, assim como de direitos políticos diversos. Essa questão vem sendo destacada

\footnotetext{
4 "Nam quod legentibus scriptura, hoc idiotis praestat pictura cernentibus, quia in ipsa ignorantes uident quod debeant, in ipsa legunt qui litteras nesciunt; unde praecipue gentibus pro lectione pictura est". (GREGÓRIO apud DUGGAN, 1989, p. 227-228). O trecho foi retirado de uma carta escrita provavelmente em outubro de 6oo. Gregório escrevera ainda uma primeira carta a Sereno sobre o mesmo tema, possivelmente em julho de 599, em que afirmava que "pinturas são usadas nas igrejas de modo que os ignorantes das letras possam pelo menos ler nas paredes por meio da visão aquilo que não podem ler nos livros" ("idcirco enim pictura in ecclesis adhibetur, ut qui litteras nesciunt saltem in parietibus uidendo legant, quae legere in codicibus non ualent"). (GREGORIO apud DUGGAN, 1989). O fato de Gregório ter necessitado escrever uma segunda carta, muito mais extensa e contundente do que a primeira, sobre o papel das imagens religiosas é uma clara indicação de que o bispo rejeitara as recomendações feitas pelo papa anteriormente. A transcrição completa da primeira carta, e de parte relevante da segunda, podem ser encontradas em Chazelle (1990, p. 139-140).

5 Para uma visão da permanência da máxima gregoriana ao longo da Idade Média, ver o já referido artigo de Lawrence Duggan. E é preciso recordar que, mesmo no século XVI, com o Concílio de Trento, essa questão ainda se mantinha atual, especialmente com relação à oposição católica à doutrina protestante, que negava o valor das imagens nos edifícios religiosos. A última sessão do Concílio, em dezembro de 1563 , voltada precisamente à discussão sobre o papel das imagens para a religião, limitou-se, essencialmente, a repetir o que Gregório havia escrito quase mil anos antes. O "Decreto sobre a invocação, a veneração e as relíquias dos santos, e sobre as imagens sagradas", resultado dessa última sessão do Concílio de Trento, é reproduzido em Lichtenstein (2004, p. 65-69).

${ }^{6}$ Afinal, como recorda Baschet, há muitas imagens "com frequência postas em lugares reservados aos clérigos ou em livros que só eles utilizam" (BASCHET, 2006, p. 495).
} 
apenas em anos mais recentes, embora esse uso específico possa ser percebido com alguma frequência nas representações religiosas ao longo da Idade Média. Conforme escreve Jérôme Baschet, não raro "as imagens [cristãs] contribuem também para construir a legitimidade do poder temporal" (BASCHET, 2006, p. 499). Há, por exemplo, cenas em que um imperador ou um determinado governante surge sendo coroado pelo próprio Cristo. Em outros casos, os modos de figuração desse mesmo governante evocariam claramente as representações do Cristo em Majestade, bastante difundidas e, portanto, muito familiares a todos os homens do Medievo. É o que ocorre em uma iluminura do Evangeliário de Oto III (980-1002), produzido por volta do ano mil: a iconografia que mostra, em uma cena, a majestade real do terceiro imperador do Sacro Império Romano-Germânico é bastante similar à tradicional representação da majestade divina do Cristo, encontrada com frequência nas absides das igrejas ${ }^{7}$. Essa iconografia recordaria também, por sua vez, os modos de representação do Cristo juiz em muitas cenas do Juízo Final ${ }^{8}$, detalhe relevante para a discussão que se deseja avançar neste artigo e que será tratado em seguida.

Há, por fim, imagens em que os temas são aqueles já tradicionalmente representados em um contexto religioso; as suas novas funções, por outro lado, se baseariam fundamentalmente na mesma interpretação (religiosa) das cenas, inserindo-as, porém, em uma conjuntura (política e/ou social) diversa, seja pelos locais em que estão figuradas, seja por elementos específicos presentes nesses mesmos lugares. Tome-se como modelo o caso particular da Capela Palatina, em Palermo - capela dos reis normandos na Sicília, construída na primeira metade do século XII. Tanto a concepção da capela como a disposição de todos os elementos em seu interior são determinantes para a constituição da interpretação política, seja da decoração mural, seja da construção como um todo: de fato, "a imagem de Cristo em majestade, que domina o trono em que o rei se encontra quando das audiências e dos atos cerimoniais importantes, contribui para sacralizar o soberano pelo eco assim criado entre sua pessoa e a de Cristo" (BASCHET, 2006, p. 500).

É nesse sentido, então, que também poderiam ser interpretadas diversas representações visuais do Juízo Final, que se relacionariam do mesmo modo tanto com questões sócio-políticas quanto com a justiça terrena. Afinal, conforme escreve Raffaella Pini, não se pode minimizar a "importância da justiça ordinária na evolução da figuração dos Juízos Finais e, mais especificamente, na representação do inferno" (PINI, 2011, p. 12), especialmente quando se considera que:

Normas que individualizam os crimes contra a religião (blasfêmia e heresia) estão presentes em todos os estatutos [em Bolonha a partir do século XIII] e confirmam a forte incidência da religião sobre a mentalidade da época, em que os crimes constituíam uma ofensa ao próximo, ao estado e a Deus. (PINI, 2011, p. 33)

\footnotetext{
7 Deve-se destacar que especificamente nesse evangeliário a associação entre o imperador e Cristo ocorre também pela proximidade entre a já referida iluminura de Oto III e outra iluminura, representando o Cristo - embora o Cristo, entronizado como o imperador na iluminura anterior, faça o gesto da benção e não segure o orbe que não raro traz em mãos; o orbe, ao contrário, é carregado na mão esquerda de Oto.

${ }^{8}$ Sobre a iconografia do Cristo juiz, e as mudanças nessa tradição iconográfica que ocorrem em meados do século XIV, ver Quírico (2013).
} 
Os desenvolvimentos da justiça terrena, as percepções sobre ela e o papel do juiz nas sociedades medievais podem, portanto, de fato ter influenciado os desenvolvimentos iconográficos e compositivos das cenas do Juízo Final. São essas as questões que serão desenvolvidas a seguir.

\section{Justiça terrena e Juízo Final}

Ao menos desde Agostinho de Hipona (354-430) desenvolveu-se na Europa ocidental a noção sobre "os efeitos benéficos da união entre justiça e paz" (GAUVARD apud SCHMITT; LE GOFF, 2002, p. 55), consideradas imprescindíveis para um bom governo. Para a adequada execução da justiça, seria fundamental que houvesse leis a serem cumpridas e, por consequência, também uma estrutura sóciopolítica que viabilizasse esse cumprimento; era necessário, por fim, que houvesse juízes que julgassem fatos e ações em conformidade às leis da sociedade que lhes conferiu seu mandato. Desde os primeiros séculos do Medievo, portanto, noções como justiça e as que dela derivariam foram recorrentes nas sociedades do Ocidente.

Julgamento é um exemplo. Este termo já comparecia com alguma frequência nas Escrituras, podendo ser compreendido de maneiras diversas. Primeiramente, ele poderia ser interpretado como todo e qualquer ato de justiça, mesmo que exercido por um indivíduo comum (e não somente a quem tivesse sido outorgado o poder de julgar); poderia significar uma sentença ou condenação pronunciada por um juiz, assim como a pena ou o castigo por um crime (conforme se lê, por exemplo, em Êxodo 12: 12: "e eu, lahweh, farei justiça [ou "exercerei meu julgamento", de acordo com outras traduções] sobre os deuses do Egito") (BíBLIA, 2004)

; o termo também poderia indicar uma lei ou uma assembleia de juízes; há ainda, por fim, os julgamentos de Deus, que usualmente significariam a condução ordinária da Providência (BERGIER, 1741, p. 344). E não se pode esquecer, sem dúvida, dentro do contexto cristão, a ideia de um julgamento da humanidade ao fim da história.

O Juízo Final, deve-se recordar, é uma das concepções mais importantes para o Cristianismo. É preciso considerar, de início, que a noção de um tempo histórico, linear, norteou o pensamento cristão desde os primeiros séculos: trata-se da crença em um tempo que progrediria constantemente, a partir de um início claramente marcado no livro do Gênesis pelo momento em que Deus criou o céu e a terra (1: 1) (BÍBLIA, 2004), para um término que indubitavelmente chegará com a Parousía, ou seja, com a segunda vinda de Cristo $^{9}$. O Seu retorno ao final dos tempos é mencionado em trechos diversos do Novo Testamento, como a

9 O termo Parousía designava, para os antigos romanos, a chegada do imperador a uma cidade ou uma província, implicando também o início de um novo período para aquela localidade - é preciso ter em conta que a visita do imperador às áreas mais distantes do Império era um evento bastante raro e singular, a ponto de levar a grandes reformas na região de forma a melhor 
seguinte passagem retirada do Evangelho de Mateus (16: 27): "pois o Filho do Homem há de vir na glória do seu Pai, com os seus anjos, e então retribuirá a cada um de acordo com o seu comportamento" (BíBLIA, 2004). Esse trecho, assim como outras passagens escriturais - tanto no Antigo como no Novo Testamentos , indicam de modo claro a noção de um julgamento baseado na conduta individual de cada homem ao longo de sua vida ${ }^{10}$. Em outro capítulo de São Mateus, também fundamental para o conceito do Juízo Final, explicita-se a noção de que, após o julgamento, a humanidade deverá ser dividida em dois grupos - os eleitos de um lado, que gozarão da visão beatífica de Deus no Paraíso por toda a eternidade, e os condenados de outro, que serão punidos ad eternum nas chamas infernais:

Quando o Filho do homem vier em sua glória, e todos os anjos com ele, então se assentará no trono da sua glória. E serão reunidas em sua presença todas as nações e ele separará os homens uns dos outros, como o pastor separa as ovelhas dos bodes, e porá as ovelhas à sua direita e os bodes à sua esquerda. Então dirá o rei aos que estiverem à sua direita: "Vinde, benditos do meu Pai, recebei por herança o Reino preparado para vós desde a fundação do mundo [...]". Em seguida, dirá aos que estiverem à sua esquerda: "Apartai-vos de mim, malditos, para o fogo eterno preparado para o diabo e para os seus anjos [...]". E irão estes para o castigo eterno enquanto os justos irão para a vida eterna. ${ }^{11}$

O Juízo Final, portanto, possui imensa importância teológica para todos os cristãos, o que é claramente indicado pelo Credo estabelecido pelo Concílio Ecumênico de Niceia, convocado pelo Imperador Constantino em 325, e ainda hoje recitado pelos cristãos, com poucas variações, durante suas celebrações religiosas: "ressuscitou ao terceiro dia, conforme as Escrituras; e subiu aos Céus, onde está sentado à direita de Deus Pai Onipotente, donde há de vir a julgar os vivos e os mortos. Creio no Espírito Santo, na Santa Igreja Católica, na comunhão dos santos, na remissão dos pecados, na ressurreição da carne, e na vida eterna"12.

Como qualquer imagem cristã, também representações do Juízo Final foram concebidas de modo a desempenhar funções religiosas diversas: dentre as mais importantes, servir como um memento para os

recebê-lo. Os primeiros cristãos absorveram o termo, adaptando-o, porém, à sua própria doutrina: Parousía, portanto, significaria o retorno de Cristo a este mundo uma última vez, quando julgará toda a humanidade por suas boas e más ações.

${ }^{10}$ Ver também, por exemplo, Hb 9: 27-28; 1Ts 4: 13-17; 2Ts 1: 6-10, assim como várias passagens dos Atos dos Apóstolos. Dentre os trechos do Antigo Testamento, igualmente interpretados como evocações da Parousía e do futuro julgamento, ver Ez 34: $17 \mathrm{e}$ 20-22; Jó 31: 6; Sl 1: 5-6; SI 49 (50): 2-6; Dn 7: 9-14 (BÍBLIA, 2004).

${ }^{11} \mathrm{Mt}$ 25: 31-34, 41 e 46. Essa passagem escritural é, sem dúvida, uma das mais conhecidas, indicando diversos elementos que serão posteriormente incorporados à iconografia do tema do Juízo Final. Além dela, outros trechos também anunciam o julgamento futuro. Esse trecho de Mateus também remete de modo claro ao trecho de Ezequiel acima mencionado, que indica da mesma forma a separação do rebanho entre ovelhas e bodes (BÍBLIA, 2004).

12 "Tertia die resurrexit a mortuis, ascendit ad coelos, sedet ad dextram Dei Patris omnipotentis, inde venturus est iudicare vivos et mortuos, Credo in Spiritum Sanctum, sanctam Ecclesian catholicam, sanctorum communionem, remissionem peccatorum, carnis resurrectionem, et vitam aeternam". 
fiéis, recordando a todos o futuro julgamento que advirá13. Assim como outras imagens cristãs, no entanto, também cenas do Juízo Final poderiam encontrar significações para além do contexto religioso. Em virtude de sua temática, associações entre o julgamento divino no último dia e julgamentos realizados pelo homem eram relativamente comuns, especialmente a partir do século XIV.

Além dos trechos escriturais que, conforme comentado anteriormente, tratariam do julgamento da humanidade no último dia, é preciso recordar que há outras passagens bíblicas que explicitariam a noção de um tribunal celeste diante do qual todo homem deverá ser julgado, ou seja, de uma estrutura celestial mais institucionalizada que evocaria modelos terrenos. Pode-se mencionar, como exemplo, um trecho da Epístola de São Paulo aos Romanos (14: 10 e 12): "Por que julgas teu irmão? E tu, por que o desprezas? Pois todos nós compareceremos ao tribunal de Deus [...]. Assim, cada um de nós prestará contas a Deus de si próprio" (BÍBLIA, 2004). Ou ainda a seguinte passagem do Livro de Daniel (7: 10): "O tribunal tomou assento e os livros foram abertos" (BíBLIA, 2004).

É assim que, segundo Baschet, "a justiça terrestre apresenta-se, então, como o reflexo da justiça divina" (BASCHET, 2006, p. 500), seja ela a justiça de um papa, de um bispo ou mesmo de autoridades laicas. Por esse motivo, cenas do julgamento final poderiam estar presentes não somente em igrejas e em outros edifícios religiosos, mas também em palácios civis e em salas de justiça municipais e eclesiásticas. No Palácio dos papas em Avignon, por exemplo, havia originalmente uma representação do Juízo Final (destruída no século XIX) na parede norte da chamada Sala da Grande Audiência, que acolhia o tribunal das causas apostólicas. Portanto, mais do que apropriado pareceria uma cena do julgamento final nesse contexto específico. Se a intenção original ao posicionar o afresco nesse local pudesse ser a de indicar a infalibilidade do tribunal, por analogia ao julgamento infalível de Cristo no último dia, é preciso levar em conta outras interpretações possíveis, que serão discutidas um pouco mais adiante.

\section{Juiz terreno versus Cristo juiz}

É a partir dessa perspectiva que se poderia interpretar o ciclo de afrescos com o tema do Juízo Final executados na Capela Madalena ou (del Podestà), no Palazzo del Bargello, em Florença (Figuras 1 e 2). Provavelmente concebido por Giotto di Bondone (ca. 1266-1337), o maior artista florentino de seu tempo, por volta de 1336, o ciclo apresenta, em paredes opostas, as cenas independentes do Juízo Final com o Inferno na parede de acesso da capela, e o Paraíso na parede de fundo ${ }^{14}$. É preciso recordar, primeiramente, que desde meados do século XIII o Palazzo del Bargello era a sede do podestà, ou seja, da figura pública que ocupava a mais alta magistratura do conselho citadino de Florença. Embora, portanto, executado no interior

${ }_{13}$ Sobre as funções religiosas de cenas com esse tema, ver Quírico (2014a), especialmente o capítulo "As funções do Juízo Final como imagem religiosa".

${ }_{14}$ Uma discussão aprofundada sobre a atribuição, a datação e também a composição das cenas é desenvolvida em Quírico (2014a), no capítulo "Dante, Giotto e as representações do Juízo Final na Toscana". 
de uma capela, esse ciclo do Juízo Final estava localizado originalmente na sede da justiça do governo florentino. Desse modo, não se poderia dissociar a interpretação desses afrescos da especificidade do local em que se encontravam. Para além das evidentes funções religiosas - especialmente quando se considera que era na capela que os condenados à morte, por vezes, aguardavam a ida ao patíbulo -, essas pinturas também teriam, sem dúvida, funções políticas.

A interpretação que a presente autora propõe para esses afrescos, assim, é a de que o podestà de Florença, de modo análogo ao Cristo no último dia, deveria ser visto como o juiz dos habitantes da cidade, e por meio dele se poderiam atingir as benesses, não do Paraíso, mas da vida terrena, através do exercício da justiça que Ihe caberia enquanto podestà da cidade. Ele seria, desse modo, na terra, a imagem do Cristo juiz que retornaria futuramente, no fim dos tempos. Ele se colocaria, por meio das pinturas giottescas da Capela del Podestà, como aquele que traria a paz e a justiça à cidade - o caminho, em suma, para o Paraíso, representado na parede de fundo da capela -, enquanto prepararia o caminho para a vinda de Cristo Salvador no último dia. A justiça, afinal, seria um dos instrumentos privilegiados pelos quais se tornaria possivel a boa governança ${ }^{15}$.

Assim como Cristo, por Seu sacrifício na cruz, é legitimado como o juiz de toda a humanidade ${ }^{16}$, também o juiz terreno seria legalmente investido do poder de fazer justiça, tendo sua autoridade outorgada pela Igreja (no caso de um juiz eclesiástico) ou pelo Estado (quando se tratasse de um juiz secular). Por sua função como juiz, deveria seguir as leis canônicas ou as civis, mas especialmente uma lei que necessariamente antecederia a todas as outras: a lei moral, revelada ou natural, cujos preceitos se imporiam universalmente (VACANT, 1925). Ecoando a ação do juiz celeste no último dia, esperava-se que também na Terra, portanto, ocorreria um julgamento justo e correto. Acreditava-se, assim, que as representações visuais do Juízo Final pudessem direcionar, de algum modo, as ações dos indivíduos, seja o homem comum, que pensaria talvez de modo mais específico no sentido religioso da cena - e talvez em particular nas consequências eternas de suas más ações ${ }^{17}$-, seja o juiz, que poderia considerar também sua interpretação política a partir da evidente associação entre seu papel no contexto jurídico (religioso ou secular) terreno e o de Cristo no último dia. Não importando qual fosse a situação, o tema aludiria de forma mais ampla a ações específicas que seriam esperadas de todo e qualquer indivíduo, visando especialmente à sua salvação no fim dos tempos.

No caso do juiz terreno, a ênfase seria dupla: a cena do Juízo Final funcionaria não somente como um memento do julgamento de Cristo no último dia; por explicitar a justiça divina, ela evocaria também, como visto, a noção de justiça terrena e, por conseguinte, a de um julgamento justo que, assim como será realizado por Cristo no fim dos tempos, deveria igualmente ser conduzido pelo juiz aqui. Por outro lado, para ele haveria ainda a constante recordação de que, caso sua ação judiciária não fosse corretamente cumprida,

\footnotetext{
${ }_{15}$ Sobre o possível aporte do pensamento de Dante Alighieri (ca. 1265-1321) sobre Giotto, que pode ter influenciado os modos de elaboração do ciclo giottesco do Palazzo del Bargello, ver o supracitado capítulo de Quírico (2014a). Há que se mencionar ain da que o artista talvez tenha retratado o poeta florentino entre os eleitos no afresco do Paraíso, indicando uma aproximação entre os dois ainda em vida.

${ }^{16}$ Sobre as relações entre a Paixão de Cristo e o Juízo Final, que não podem ser desenvolvidas a contento aqui, ver Quírico (2015).

${ }^{17}$ Para uma análise dessa questão, remete-se uma vez mais ao capítulo "As funções do Juízo Final como imagem religiosa", em Quírico (2014a).
} 
haveria consequências eternas; afinal, o julgamento terreno é necessariamente limitado e submetido a uma autoridade superior, celestial. Em suma, o poder do juiz terreno será, no último dia, analisado pelo juiz divino, assim como todas as suas outras ações em vida. As representações visuais do Juízo Final nos contextos abordados por este artigo, portanto, mostrariam não somente um evento futuro, mas evocariam também as possíveis consequências de toda e qualquer decisão tomada nesses mesmos tribunais.

Essa mensagem poderia ser reforçada de várias formas. Segundo a tradição iconográfica medieval, tornou-se comum, nos últimos séculos do Medievo, a inclusão de inscrições nas cenas infernais, que identificariam de forma clara os pecadores. É o que ocorre, por exemplo, em dois grandes ciclos de afrescos produzidos na Toscana na segunda metade do século XIV: o de Nardo di Cione, finalizado por volta de 1357 na Capela Strozzi, na Igreja de Santa Maria Novella, em Florença, e o ciclo de Taddeo di Bartolo no interior da Collegiata de Santa Maria Assunta, em San Gimignano, de ca. 1393. Se no afresco de Taddeo di Bartolo os pecados capitais são destacados - la superbia, la vidia, la lussuria, la varitia (soberba, inveja, luxúria e avareza), no ciclo florentino Nardo di Cione incluiu também sentenças que explicavam quais pecadores eram punidos naqueles círculos específicos: Qui sono puniti gli impostori e gli indovini ("aqui são punidos os impostores e os adivinhos"); Qui si puniscono coloro che poetero (sic) consiglio fraudolento ("aqui se punem aqueles que deram conselho fraudulento"); Qui sono puniti gli iracondi e accidiosi ("aqui são punidos os iracundos e os preguiçosos"), dentre outras ${ }^{18}$.

Em ao menos um exemplo, no entanto, tem-se uma situação diferente. Refere-se aqui ao monumental afresco da fachada interna da Igreja da Santissima Annunziata, em Sant'Agata de' Goti (cidade localizada na região da Campânia, na Península Itálica), executado talvez entre 1430 e 1435 (Figura 3). Nessa pintura, além dos tituli que nomeiam pecadores particulares (podem-se ler, por exemplo, as identificações fornicator, traditor, ruffiana - fornicador, traidor, cafetina), há profissionais ligados a ocupações específicas que são ainda hoje perfeitamente reconhecidas entre os condenados punidos no Inferno. Eles são discerníveis não apenas pelas inscrições que também os acompanham, mas também pelas características iconográficas de seus instrumentos de trabalho. Embora esse afresco esteja em uma igreja, e não em um tribunal, palácio de justiça ou algum outro edifício que se relacionaria de forma mais evidente a julgamentos ou à justiça terrena, a singular iconografia da cena permite a aproximação dessa obra com a análise desenvolvida aqui.

Deve-se destacar, inicialmente, que as representações visuais do Juízo Final, nos últimos séculos da Idade Média, desenvolveram-se particularmente no que se refere às figurações das instâncias do Além, Paraíso e Inferno, em especial deste último. Uma das questões principais a nortear as formas de representação da região infernal seria a de buscar uma mensagem clara, de modo que ela fosse corretamente compreendida e também que suas funções como imagens religiosas fossem cumpridas. Assim, com toda probabilidade visando a uma facilidade de reconhecimento por parte dos fiéis que observassem as cenas infernais, foi necessário que as figurações do Inferno, embora imaginadas e irreais,

\footnotetext{
${ }^{18}$ Um exemplo diverso, mas complementar, são os afrescos do Juízo Final e do Inferno que compõem o ciclo do Trionfo dela Morte, no Camposanto de Pisa, pintado possivelmente pelo artista florentino Buonamico Buffalmacco entre 1336 e 1341 . Nesse caso, as inscrições iam além da identificação dos diversos tipos de pecadores representados no afresco do Inferno: havia um memento constante dirigido aos fiéis, através das inscrições que ainda eram legíveis no fim do século XIX, enfatizando a necessidade de se olhar atentamente as imagens para absorver de modo adequado a sua mensagem. Sobre isso, ver Quírico (2014a).
} 
partissem necessariamente da realidade deste mundo. Conforme escreve Raffaella Pini, essas cenas "deveriam representar uma realidade bem conhecida, vista nas estradas citadinas ou conhecida através de relatos, que os afrescos fixavam em uma imagem viva e indelével na parede e na mente dos observadores" (PINI, 2011, p. 11). Portanto, pode-se talvez estabelecer uma relação entre a maior descrição dos crimes e das penas, que passou a ocorrer nas legislações citadinas (segundo mostra Pini em seu estudo), e o maior detalhamento iconográfico das cenas infernais.

É a partir dessa ótica que podem ser interpretadas algumas das punições vistas em representações do Inferno: em algumas obras, instrumentos de tortura judicial coevos podem ser discernidos, e as punições figuradas seriam as mesmas concedidas aos infratores do período. Assim, há pinturas em que se veem torturas como o esmagamento de ossos, mãos decepadas e esmagamento da espinha. No afresco com o tema do Juízo Final pintado possivelmente entre 1305 e 1307 por Giotto na Capela Scrovegni, em Pádua, distinguem-se também outras alusões a castigos usuais na Toscana do Trecento, como figuras penduradas de cabeça para baixo, o que era considerado uma forma bastante vergonhosa de punição capital na época (BARNES, 1998, p. 18).

Além dos castigos, é importante destacar ainda que muitos dos instrumentos de tortura que demônios utilizam em diversas cenas infernais podem perfeitamente ser identificados com utensílios comuns, como alicates e panelas (e é sempre importante destacar como a noção de uma panela borbulhante, onde os condenados são cozidos, é possivelmente uma das mais poderosas visões infernais, mesmo na contemporaneidade). Como explica Barbara Palmer, em alguns exemplos "são as ferramentas da terra, transferidas por suas ligações semânticas dos implementos necessários para a realização de um trabalho e o conceito de trabalho sendo tortura literal" (PALMER apud DAVIDSON; SEILER, 1992, p. 25). No afresco de Sant'Agata de' Goti também há torturas que se inseririam dentro dessa tradição iconográfica: a figura identificada como "Juliano apóstata" [Figura 4], por exemplo, é cindida ao meio por dois demônios alados que, para tanto, empregam uma serra idêntica àquelas usadas em trabalhos de marcenaria ${ }^{19}$.

Essa pintura, porém, possui ainda outras particularidades: conforme mencionado anteriormente, nela igualmente se veem, entre os condenados nas chamas do Inferno, diversos profissionais claramente discerníveis em suas ocupações diárias, dentre eles um juiz, identificado de modo inequívoco, ademais, por uma inscrição (iudex) (Figura 5). Considerando-se a tradição iconográfica que, ao menos desde o século XIV (mas que possivelmente tem origens no século XIII), associava claramente nas representações visuais o tipo de pecado cometido em vida à punição que se receberia no Além ${ }^{20}$, pode-se inferir que, com relação a esse detalhe específico, a explicitação do cargo ocupado em vida por esse pecador certamente teria relação direta com os motivos porque ele estaria condenado no Inferno. Especialmente ao se considerar que o juiz, assim como os outros pecadores identificados por suas profissões, é simplesmente mostrado como se

\footnotetext{
19 Para uma análise sobre a inclusão do Imperador Juliano (361-363) com a tiara papal no afresco de Sant'Agata de' Goti - um detalhe bastante singular na iconografia do Inferno -, ver Palleschi (apud FRUGONI, 2004, p. 49-54).

${ }^{20}$ Essa associação entre pecado e pena que se percebe nas cenas infernais deriva tanto dos manuais de penitência quanto das visões do Além, de grande popularidade ao longo de toda a Idade Média. Isso poderia explicar, por exemplo, a constante presença dos pecados capitais nas figurações do Inferno. Para uma análise mais aprofundada sobre as representações visuais do Inferno, ver Baschet (1993), Quírico (2011), e Quírico (2014b). Ver também Pini (2011), para um estudo sobre as relações entre os desenvolvimentos da iconografia infernal e os códigos estatutários da Bolonha do século XV.
} 
estivesse trabalhando, enquanto uma serpente se apoia em seus ombros. O juiz está sentado ao lado de um notarius (também identificado pela inscrição a seu lado), com quem divide uma mesa e parece entretido a conversar; o primeiro segura um códice, o segundo um pergaminho, ambos abertos. Não há, além das chamas que os cercam, qualquer punição evidente; esse detalhe tornaria ainda mais explícita a interpretação proposta, ou seja, de que teria sido o exercício equivocado de seu cargo o provável motivo que os levou à condenação eterna. Segundo Chiara Frugoni, eles seriam pecadores "que habitam a casa de Satanás porque sua profissão lhes condenou" (FRUGONI apud FRUGONI, 2004, p. 6).

Deve-se ressaltar, por outro lado, que há ainda no afresco outros condenados cuja figuração segue essa descrita acima: assim como o juiz e o notário, há um banqueiro (posicionado imediatamente acima desses dois). Além deles, encontra-se também no "exercício de sua profissão" (para utilizar uma expressão empregada por Roberta Palleschi em seu estudo sobre Sant'Agata de' Goti) um ferreiro, igualmente identificado por uma inscrição (ferraro) (Figura 4). Os três primeiros condenados integrariam um grupo de profissões cujas ações e decisões seriam mais comumente vistas de modo negativo (e o fato de isso ocorrer em um afresco do século XV indica que essa interpretação, tão associada às sociedades contemporâneas, encontraria suas raízes em épocas muito mais antigas) e, portanto, mais facilmente "condenáveis" ao Inferno do que outros ofícios, vistos como mais idôneos. A inclusão, porém, também de um simples ferreiro mostra como um estudo mais aprofundado dessas figurações deveria necessariamente levar em consideração as profundas modificações que ocorreram nas sociedades medievais nos últimos séculos da Idade Média. Afinal, como escreve Palleschi,

Como a sociedade se tornava sempre mais complexa e articulada, também o imaginário infernal se adequava às mudanças da vida terrena, aproximando dos pecadores condenados por terem cometidos vícios capitais também aqueles que haviam cometido pecados ligados ao exercício da própria profissão (PALLESCHI apud FRUGONI, 2004, p. 72).

Chegando-se à conclusão desse estudo, pode-se perceber, então, como as diversas análises e interpretações possíveis de representações visuais do tema do Juízo Final brevemente discutidas poderiam estar inter-relacionadas; mesmo que eventuais conotações sócio-políticas da cena fossem essenciais para sua correta e plena compreensão nos contextos diversos em que pudessem estar inseridas, elas, ao fim de tudo, estariam subordinadas ao mais importante papel que imagens do Juízo Final possuiriam no contexto religioso cristão: servir de admoestação a todos que as contemplassem. Mesmo para um juiz no exercício de sua profissão, essas representações evocariam as palavras de Eclesiástico 7: 36: "Em todas as tuas obras, lembra-te do fim, e jamais pecarás". Afinal, o malfeito do juiz terreno em vida será cobrado futuramente pelo juiz divino no último dia. 


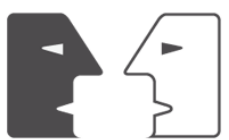

ANTÍTESES

\section{Caderno de Imagens}

Figura 1 - Giotto e seguidores. Paraíso. Capela da Madalena (ou del Podestà), Palazzo del Bargello, Florença, ca. 1336-1337.

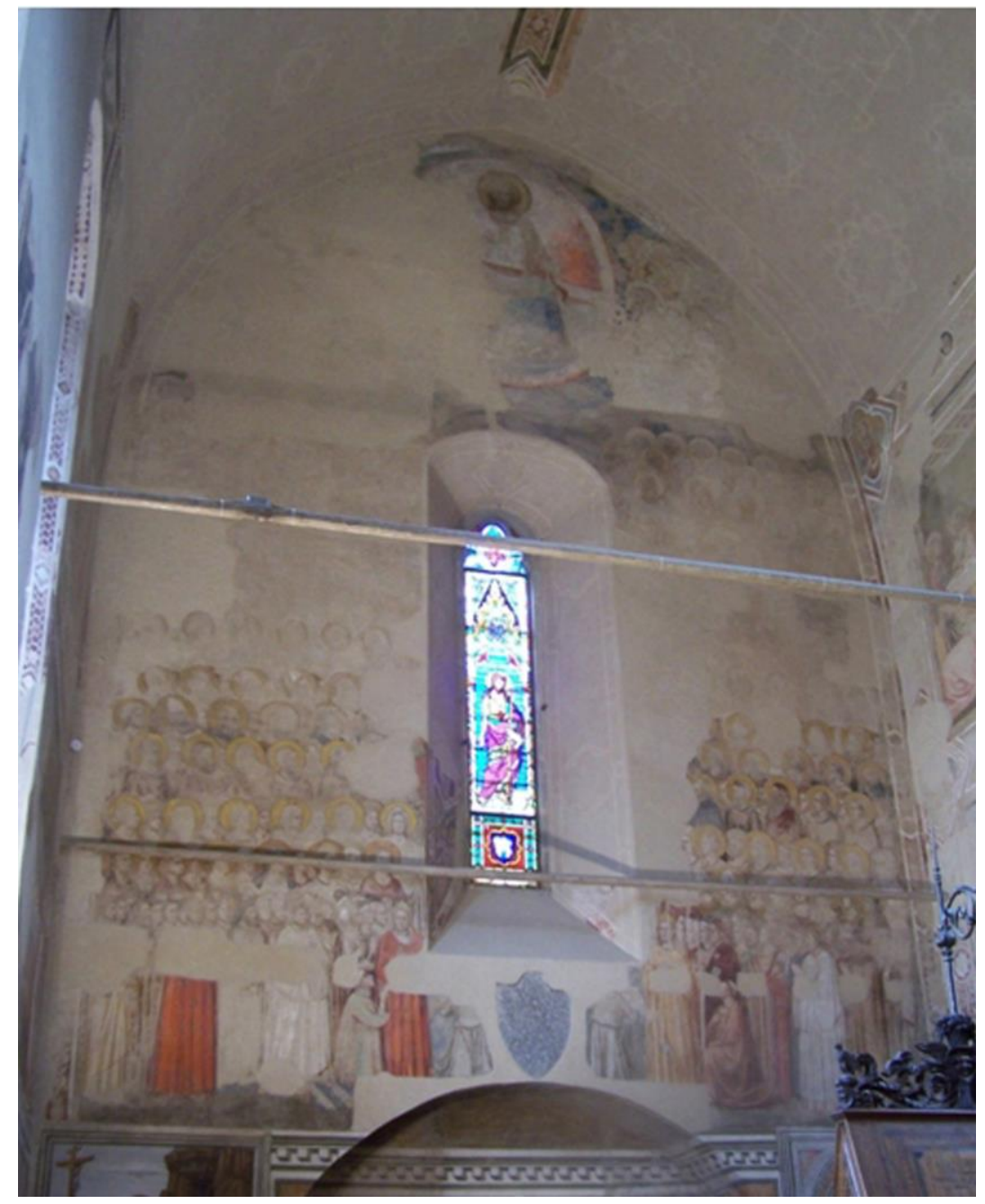

Fonte: Acervo do Autor. 


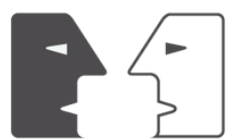

ANTÍTESES

Figura 2 - Giotto e seguidores. Juízo Final. Capela da Madalena (ou del Podestà), Palazzo del Bargello, Florença, ca. 1336-1337.

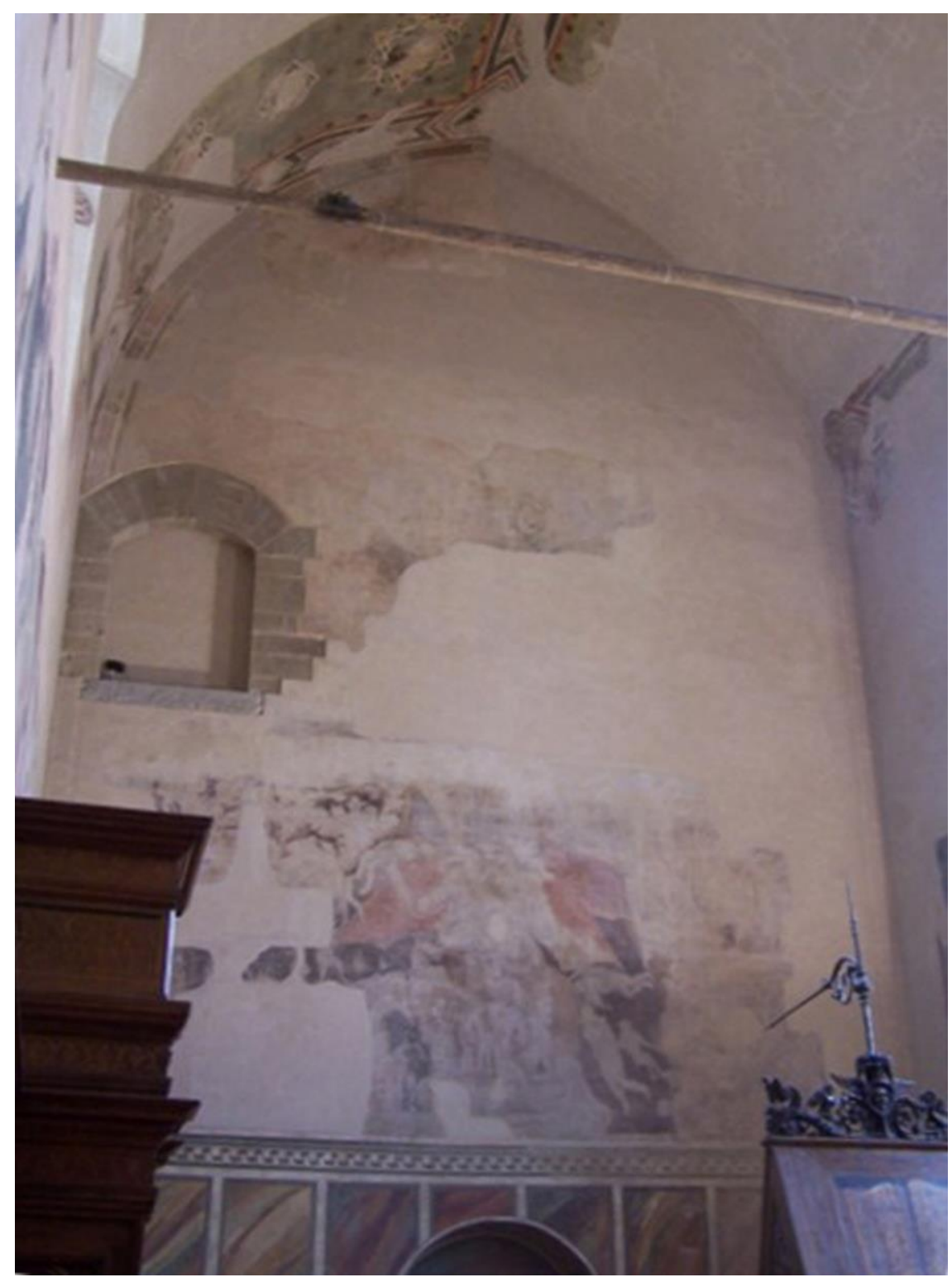

Fonte: Acervo do Autor. 


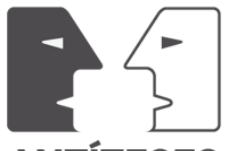

ANTÍTESES

Figura 3 - Artista desconhecido. Juízo Final. Igreja da Santissima Annunziata, Sant'Agata de' Goti, ca. 1430-35.

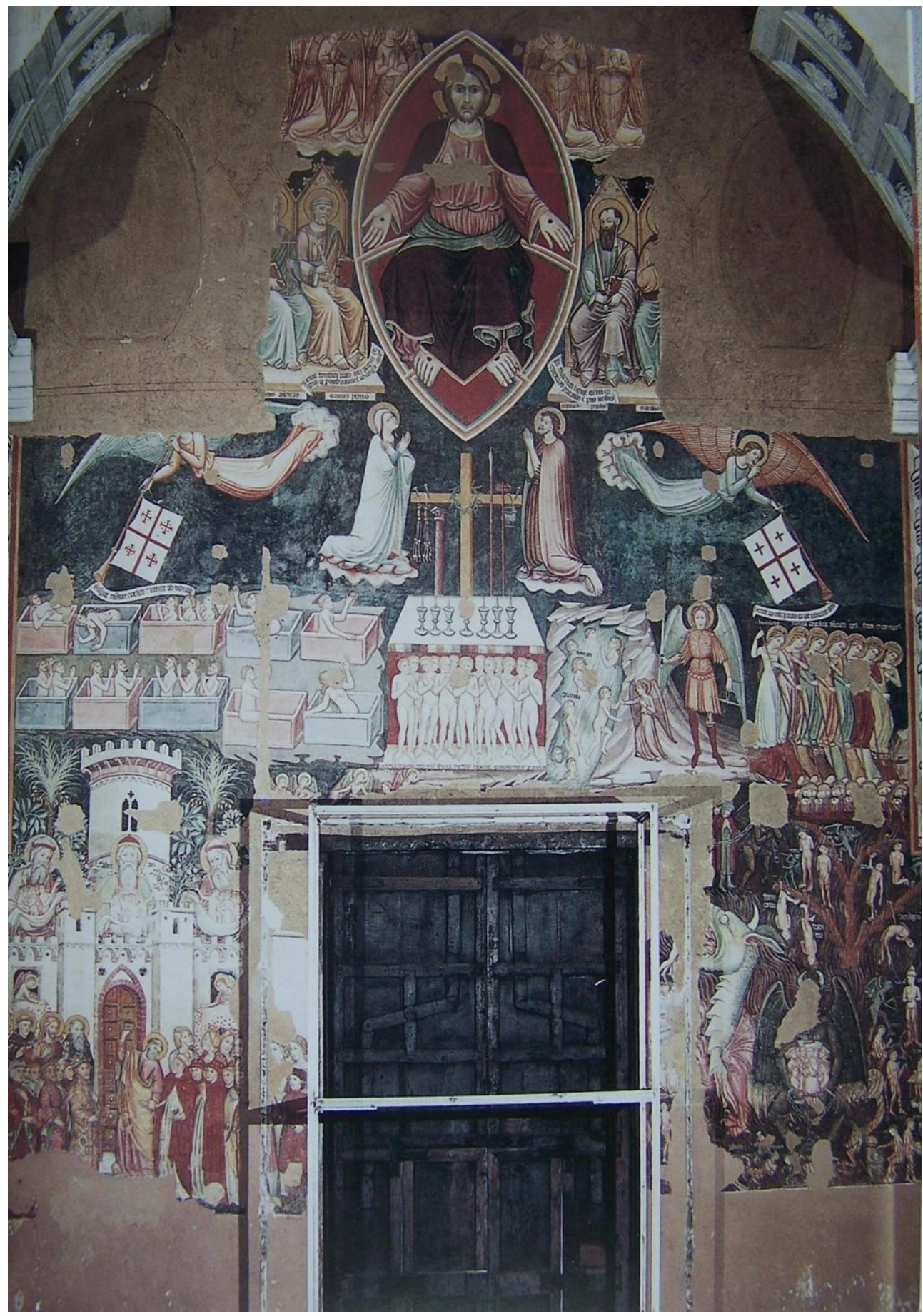

Fonte: Frugoni (2004). 


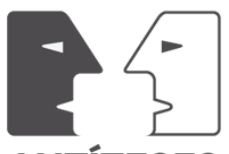

ANTÍTESES

Figura 4 - Artista desconhecido. Juízo Final, detalhe do Inferno. Igreja da Santissima Annunziata, Sant'Agata de' Goti, ca. 1430-35.

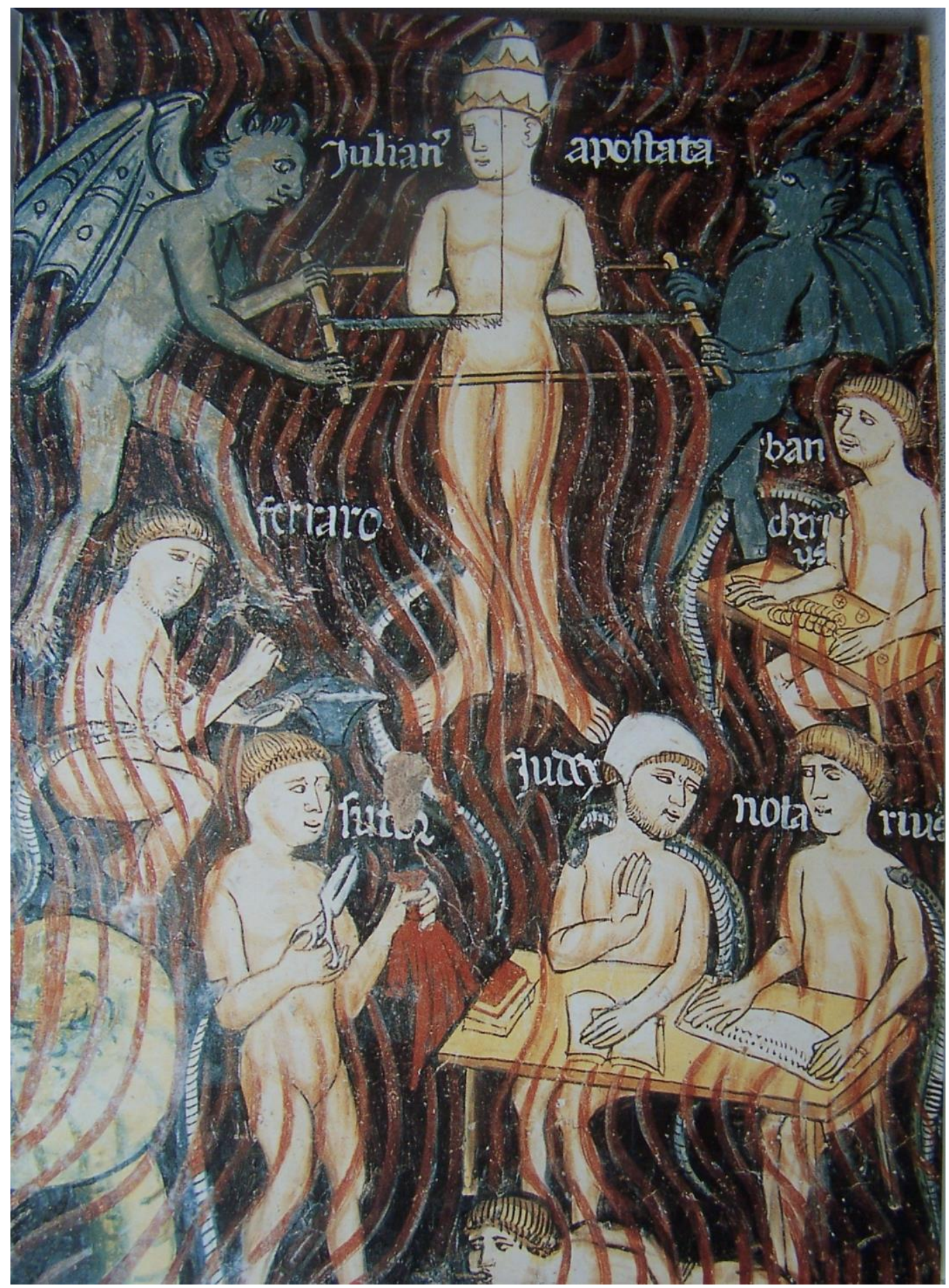

Fonte: Frugoni (2004). 


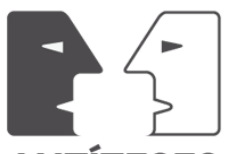

ANTÍTESES

Figura 5 - Artista desconhecido. Juizo Final, detalhe do Inferno. Igreja da Santissima Annunziata, Sant'Agata de' Goti, ca. 1430-35.

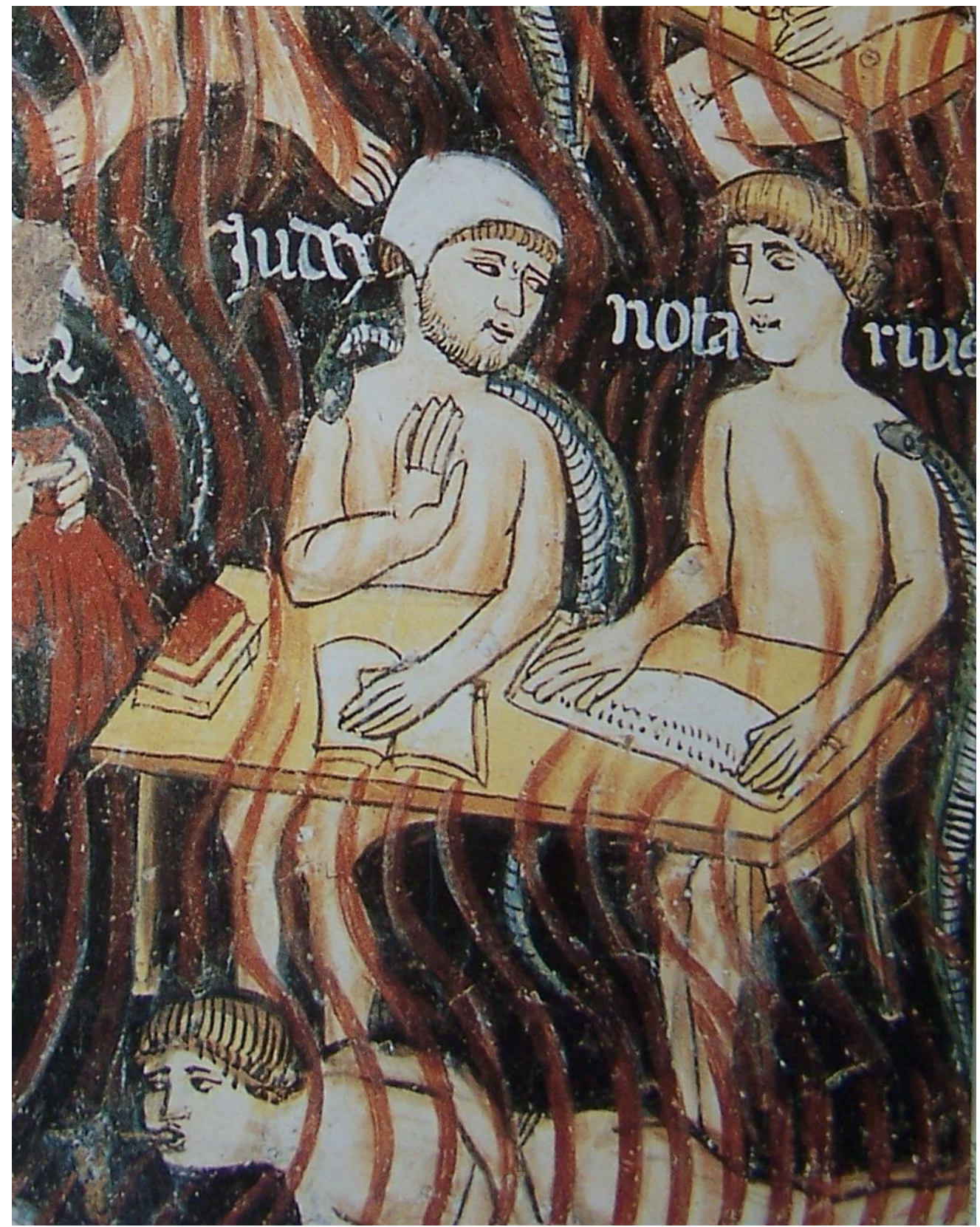

Fonte: Frugoni (2004). 


\section{Referências}

BARNES, B. Michelangelo's last judgment: the renaissance response. Berkeley: University of California, 1998.

BASCHET, J. A expansão ocidental das imagens. In: . A civilização feudal. São Paulo: Globo, 2006. p. 481-523.

BASCHET, J. Les justices de l'au-delà. Les représentations de l'enfer en France et en Italie (XII ${ }^{\mathrm{e}} \mathrm{XV} \mathrm{V}^{\mathrm{e}}$ siècle). Roma: École Française de Rome, 1993.

BASCHET, J. Lieu sacré, lieu d'images: les fresques de Bominaco (Abruzzo, 1263): thème, parcours, fonctions. Roma: École Française de Rome, 1991.

BELTING, H. Semelhança e presença: a história da imagem antes da era da arte. Rio de Janeiro: Ars Urbe, 2010.

BERGIER, N. Dictionnaire de théologie. Paris: Outhenin-Chalandre Fils, Editeur, 1741. v. 4.

BÍBLIA. Português. Bíblia de Jerusalém. Nova edição, revista e ampliada. São Paulo: Paulus, 2004.

CHAZELLE, C. M. Pictures, books, and the illiterate: Pope Gregory i's letters to Serenus of Marseilles. Word and Image, London, v. 6, n. 2, 1990.

DAVIDSON, C.; SEILER, T. H. (Org.). The iconography of hell. Kalamazoo: Western Michigan University, 1992.

DUGGAN, L. G. Was art really the 'book of the illiterate'?. Word and Image, London, v. 5, n. 3, 1989.

FRUGONI, C. (Org.). Lavorare all'inferno: Gli affreschi di Sant'Agata de' Goti. Roma: Laterza, 2004.

LICHTENSTEIN, J. (Org.). A pintura. São Paulo: Editora 34, 2004. (Textos essenciais, 2).

PINI, R. Le giustizie dipinte: la raffigurazione della giustizia nella Bologna rinascimentale. Bolonha: Minerva, 2011.

QUÍRICO, T. A iconografia do inferno na tradição artística medieval. Mirabilia, v. 12, jan./jun. 2011.

QUÍRICO, T. A morte de Deus e a morte do homem: Paixão de Cristo, Juízo final e triunfo da morte no fim da idade média. Nava, Juíz de Fora, v. 1, n. 1, p. 8-25, jul./dez. 2015.

QUÍRICO, T. A representação do Cristo juiz em pinturas toscanas do trecento ao cinquecento. Concinnitas, Rio de Janeiro, v. 2, n. 23, dez. 2013.

QUÍRICO, T. Inferno e paradiso: as representações do juízo final na pintura toscana do século XIV. Campinas: 
Unicamp, 2014a.

QUÍRICO, T. The representation of heaven and hell in last judgement scenes. In: PICCAT, M.; RAMELLO, L. (Org.). Memento mori. Il genere macabro in Europa dal Medioevo a oggi. Alessandria: Edizioni dell'Orso, 2014b. p. 571-588.

ROTHSTEIN, B. Sight and spirituality in early netherlandish painting. Cambridge: Cambridge University, 2005.

SCHMITT, J. C. O corpo das imagens: ensaios sobre a cultura visual na idade média. Bauru: EDUSC, 2007.

SCHMITT, J. C.; LE GOFF, J. (Org.) Dicionário temático do Ocidente medieval. Bauru: EDUSC, 2002.

VACANT, A. Dictionnaire de théologie catholique. Paris: Letouzey, 1925. v. 8.

Recebido em 20/04/2016 - Aprovado em 10/06/2016. 